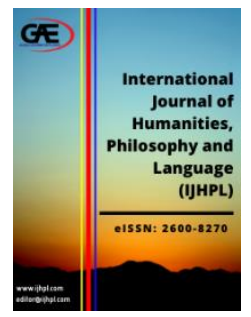

\author{
INTERNATIONAL JOURNAL OF \\ HUMANITIES, PHILOSOPHY \\ AND LANGUAGE \\ (IJHPL) \\ www.ijhpl.com
}

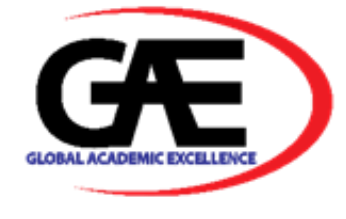

\title{
THE DEVELOPMENT OF GOOD PRACTICES FOR ENGLISH LANGUAGE TEACHER REDEPLOYMENT POLICY IMPLEMENTATION IN MALAYSIA
}

\author{
Nor Hisham Ismail $^{1 *}$, Hamidah Yusof ${ }^{2}$, Khalip Musa ${ }^{3}$ \\ 1 Faculty of Management and Economic, Universiti Pendidikan Sultan Idris (UPSI), Malaysia \\ Email: shambppdp@gmail.com \\ 2 Faculty of Management and Economic, Universiti Pendidikan Sultan Idris (UPSI), Malaysia \\ Email: hamidah.yusof@upsi.edu.my \\ 3 Faculty of Management and Economic, Universiti Pendidikan Sultan Idris (UPSI), Malaysia, \\ E-mail: khalip@upsi.edu.my \\ * Corresponding Author
}

\section{Article Info:}

\section{Article history:}

Received date: 15.07 .2020

Revised date: 26.07 .2020

Accepted date: 30.11 .2020

Published date: 01.12.2020

\section{To cite this document:}

Ismail, N. H., Yusof, H., \& Musa, K. (2020). The Development of Good Practices for English Language Teacher Redeployment Policy Implementation in Malaysia. International Journal of Humanities, Philosophy and Language, 3 (12), 1328.

DOI: $10.35631 /$ IJHPL.312002.

This work is licensed under $\underline{\text { C BY } 4.0}$

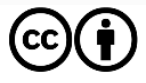

\begin{abstract}
:
The quality of English teachers in schools is one of the contributing factors in students' proficiency in the language. Hence, the purpose of this study was to explore and develop teacher redeployment good practices. The needs analysis of this study discovered the themes of redeployment good practices. This study used the triangulation method in collecting information from interviews, observation, and document analysis. Fuzzy Delphi Method (FDM) was adopted to develop good practices of teacher redeployment policy implementation based on the consensus of experts. There were six themes constructed and 42 sub items supported the themes to develop the redeployment policy implementation best practices priority list. 15 panel of experts responded to Five-Likert linguistic scale survey questionnaires. The threshold value (d) must exceed $75 \%$ to verify the experts' consensus, while the alpha-cut value $>0.5$ was used to select the items. This study showed a high consensus agreement among the experts for themes with (d) values at $85.7 \%$ in terms of the Teacher Selection Based on Professional Background $($ Amax $=0.79)$, Interventions $($ Amax $=0.78)$, Teacher Readiness $($ Amax $=$ 0.77), Implementation of The Guidelines (Amax $=0.77)$, Teacher Selection Based on Personal Background (Amax = 0.77), the Enforcement of Policy Implementation $(A \max =0.74)$ and all values exceeded the minimum of 0.60 . Therefore, based on the findings, the implication of the study recommends the policymakers to review the current redeployment guidelines so that it can support the efforts to minimize mismatch of English teachers in terms of the
\end{abstract}


location and option thus will improve the management of the policy implementation.

Keywords:

Redeployment, Mismatch, English Optionists, Policy Implementation

\section{Introduction}

English Language proficiency among students became the national issues that challenged the related policy initiatives implemented. This could lead to unclear guidance for future decision making and policy implementation. The uncertainty of the policy outcomes influenced future processes of policy planning and implementation. (Alaerts, 2020; Hoof, Kraan, Visser, Avoyan, Batsleer, \& Trapman, 2019; Nurani et. al., 2018). In Malaysia, the supply of English language teachers in schools was statistically sufficient but English optionists have not been distributed accordingly and resulted to mismatch of English teachers in schools (EPRD, 2017).

The Ministry of Education (MoE) distributed teachers to schools based on the Management Expenditure Estimation (EME) for the school-based posts. Problems occurred when the distribution of teachers was not done based on their options (BPPDP, 2013b). When this process was not done accordingly, schools would not get the rightful number of teachers which resulted to teacher shortage. Consequently, the non-optionists would have to teach the subject and this had been one of the setbacks in the teaching and learning of English (BenDavid-Hadar, 2015; Hamidah, 2011). Thus, redeployment had been the policy decision that could resolve the related issues of teacher mismatch in schools.

The implementation of redeployment policy among English teachers sparked a lot of frustration among teachers especially those who were not very happy to be transferred to locations which was not to their advantages (BPPDP, 2012). However, little work had been done to address issues and as a result, policy implementers had no clear guidance and reference on the aspects of effective implementation of the policy. Hence, this research is important to explore the issues that hindered effective implementation of teacher redeployment policy. Experts' opinions on the policy implementation practices could highlight better insights to the real issues and problems.

\section{Statement of Problem}

The English language teacher redeployment is a policy strategy that needs to be implemented but the states and districts offices are still facing challenges to ensure that the implementation of redeployment takes place accordingly to minimize teacher mismatch. In addition, the ultimate aim of this policy strategy is to ensure that each school gets the rightful number of qualified English language teachers based on the Estimated Management Expenditure (ABM). Hence, the schools will have qualified English language teachers teaching the subject (MOE, 2010d; MOE, 2010c).

Quality English language teachers was one of the major factors influenced English language usage and acquisition in schools (BPPDP, 2013a). Although there were enough English language teachers being trained by $\mathrm{MoE}$, the distribution and redeployment of teachers for the subject in primary and secondary schools causes a lot of issues. Educational Planning and Copyright $\odot$ GLOBAL ACADEMIC EXCELLENCE (M) SDN BHD - All rights reserved 


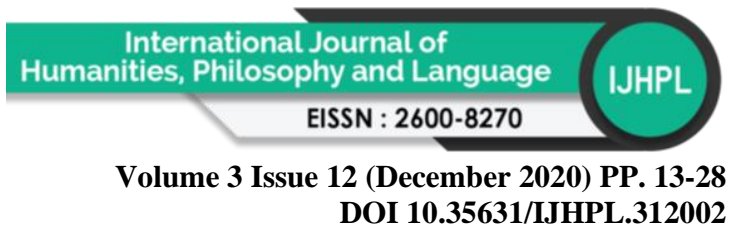

Research Division (EPRD), Ministry of Education Malaysia reported that in October 2017, there were 33,262 English language teachers in the primary schools and there were 28,671 English language teachers who were teaching the subject in schools, whereas 4,591 teachers who are not English optionists, were teaching English subject in primary schools. In the case of secondary schools, there were 18,295 English language teachers and there were 16,663 were teaching the subject whereas 1,632 were not teaching English. On the other hand, 5,124 nonoptioned English teachers were teaching English in the secondary schools. Unless redeployment is effectively implemented, an estimated 4000 mismatches every year will continually affect the quality teaching and learning of English in Malaysian schools.

\section{Purpose}

The aim of the implementation of teacher redeployment is to address the problem of ineffective distribution of teachers especially between rural schools and urban schools. (Ndhlovu, 1996; Wang Chih Fong, 2005; Nemutandani, 2004). The purpose of redeployment of English language teachers in Malaysia is to ensure that all schools should have enough professionally trained English optionists to help improve students' learning of English. Even though redeployment seems to be the practical exercise to ensure equitable distribution of English language teachers in the country, it is claimed to be unjust for the teachers who have settled down at the place where they are currently teaching (BPPDP, 2012).

The main purpose of this study is to investigate best practices that could address the challenges in the implementation of the policy. At the same time, this study aims to get the consensus of policy experts on the policy implementation practices that can help to guide the implementation of redeployment to minimize the misdistribution of English language teachers to schools in Malaysia.

\section{Objectives}

Based on the purpose of the study, the research objectives to be achieved are;

(a) to explore the themes of the redeployment policy implementation good practices based on the mechanisms and strategies exercised by policy implementers;

(b) to get the consensus of experts on the priority list of the redeployment policy implementation good practices.

\section{Literature Review}

The academic performance of English Language among students in schools became the national issues that have challenged the policy initiatives taken by the government. The scenario led to unclear guidance for future decision making and policy implementation mechanism. The uncertainty of the policy outcomes may influence future process of policy analysis, planning and implementation by stakeholders. (Alaerts, 2020; Hoof, et. al., 2019; Nuraini et. al., 2018; Mavrogordato \& White, 2017; Olavarria-Gambi, 2017).

Various scholars of policy analysis have an overlapping methodology in policy analysis which works around the definition of the problem. Most policy analysts look at the problem before embarking on the approach to select the means to solve the problem (Dunn, 2008; Okamoto, 2008; Sabatier, 2007; Weimer \& Vining, 2005; Dunn, 2004; Heck, 2004; Hussein Sufean, 2000; Patton \& Sawicki, 1993; Dunn, 1981). Failure to identify policy problems led to mistakes 


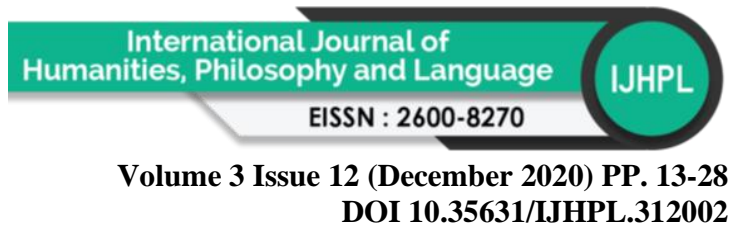

in suggesting policy alternatives and implementation of ineffective policy programs (Okamoto, 2008). Consequently, not only the current problems will be unresolved but new problems may occur.

Thus, it is essential for policy makers to explore the effectiveness of policy implementation mechanisms. Various factors determine the quality of teaching in a school which include the available resources, curriculum, instructional leadership, and it is also driven by the individuals who teach in each classroom (S. Loeb \& J. Myung, 2020). In the case of redeployment of English Language teacher policy implementation, even though the demand of teachers is set to grow rapidly over the next decade, government should develop effective strategies for teachers by taking into account the policies related to the human resources that affecting the morale and quality of teachers (Zengele, 2019; Clarke \& McFlynn, 2019; Rapeta, 2019; Ginsburg, et al., 2018; Rai, et al., 2017)

The process of redeployment should begin with the concept of rationalisation which means the redistribution of resources, human and materials, from where there is an over-supply to where there is an under-supply even though implementation of redeployment against their will led them to lose their morale and motivation. (Woolcock, 2018; Dwangu, 2018; Mukeredzi, 2016; Gasa, 2016). Although teacher distribution can be based on student-teacher ratio, government policies concerning downsizing, redeployment, early retirement, and rapid curriculum change produces stress among the teachers. Furthermore, the outcome of redeployment policy may impact schools to losing good teachers especially when the government have strict guidelines to acknowledge teachers to be qualified in teaching a specific subject most likely because of the unclear policies on redeployment and promotions (Thuo, 2019; Villiers, 2016; Yusoff \& Azam, 2017; Yani \& Rosita, 2016; Susani, 2017). As a result, policies to redistribute education resources like redeployment policy must consider the outcomes in various educational spectrum because educational capability correlate with organizational commitment especially in relation to human capital development (Zaitseva, et al., 2020; Bhandari \& Mueller, 2018; Kumar, Manonmani, \& Kumar, 2018; Higgins, Maber, Lopes Cardozo, \& Shah, 2016; Flaherty, 2017). Thus, when there are still gap between the policy implementation exercise and the current mismatch of English language teachers, this study is timely. Since redeployment is inevitable and must be implemented to resolve the issue of mismatch, the best practices policy implementation priority could help policy implementers to ensure redeployment is implemented accordingly.

\section{Research Methodology}

This study adopted the exploratory sequential mixed methodology (Cresswell, 2012).

\section{Procedures}

This study adapted the Fuzzy Delphi technique to evaluate the list of redeployment strategies extracted from the survey involving the policy stakeholders. The questionnaires for the Fuzzy Delphi approach were developed through information gathered via triangulation method. Adopting the triangulation method, the researcher combined the interview techniques, observation and document analysis in the data collection to provide input on the redeployment implementation strategies. The questionnaires were then piloted before it was sent to the Delphi panel of experts for their responses. The questionnaires were collected from each of the panel 


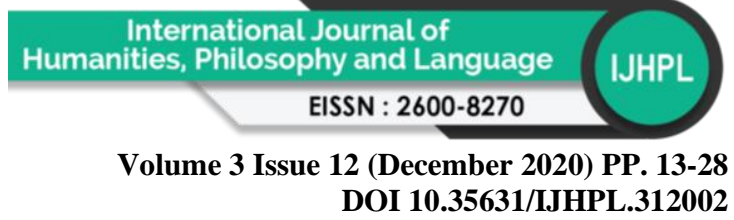

and percentage of agreement for each of the item were calculated to determine if the item(s) should remain in the list or should be omitted. Using Fuzzy Delphi Method (FDM), a list of prioritized English language teacher redeployment best practices was developed and ranked based on the consensus of the panel of experts.

\section{Samples}

The participants were chosen via purposive sampling as agreed by Merriam (2010) and Robson (2002). Three candidates were interviewed to gather data in developing the questionnaires. They were redeployment desk officers from the district education offices. They were recommended by snowball sampling. 15 Delphi panel of experts helped in providing valuable feedbacks on the list of redeployment best practices via the questionnaires. For the purpose of this study, the panel of experts were officers from the education district offices, state education departments and divisions in the ministry who were the desk officers for redeployment and also school principals and the senior assistants. The selection of the respondents for the interviews and the experts for this study were based on the following aspects as suggested by Hsu \& Sandford (2007):

i. $\quad$ the disciplinary areas of expertise in teacher redeployment policy;

ii. panelists' background and experiences concerning redeployment policy implementation;

iii. capability of panelists to contribute helpful inputs and feedbacks; and

iv. panelists' willingness to review their initial or previous judgments for the purpose of reaching or attaining consensus.

\section{Data Analysis}

Analysis of data using FDM consists of Likert-type surveys (Table 1) that are designed for the panel of experts to rate the items from the questionnaires. Using the FDM questionnaire survey form, the panel of experts finalized their decision on items to be included and items to be omitted from the list. The list of items which have been agreed upon by panel of experts were then evaluated using Fuzzy Delphi technique to determine the rank of priority. The results of the analysis confirmed the rank of each redeployment good practice.

FDM consists of two important criteria which are the Triangular Fuzzy Number and Defuzzification Process.

Table 1: Sample of Linguistic Scale

\begin{tabular}{lrrr}
\hline 5 Point Linguistic Scale & $\mathrm{m}_{1}$ & $\mathrm{~m}_{2}$ & $\mathrm{~m}_{3}$ \\
\hline Strongly Agree & 0.60 & 0.80 & 1.00 \\
Agree & 0.40 & 0.60 & 0.80 \\
Moderately Agree & 0.20 & 0.40 & 0.60 \\
Disagree & 0.10 & 0.20 & 0.40 \\
Strongly Disagree & 0.00 & 0.10 & 0.20 \\
\hline
\end{tabular}

\section{Triangular Fuzzy Number}

Triangular Fuzzy Number consists of 3 values $\left(m_{1}, m_{2}, m_{3}\right)$ in which the minimum value, the plausible value and maximum value are shown in Figure 1 below: 


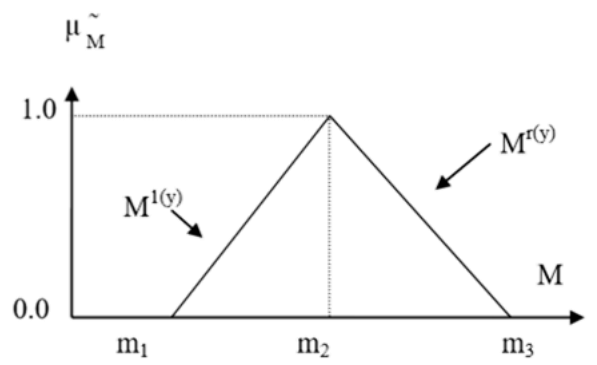

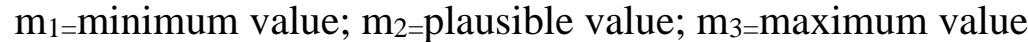

Figure 1: Triangular Fuzzy Number

Similar to Likert scale, the Triangular Fuzzy number are used to translate the linguistic scales to a set of fuzzy number. The higher the scale, the higher the accuracy of the responses. The number of agreement scale is in odd numbers of 3,5 or 7 point of linguistic scales. The 5-point linguistic scales were used in this study as shown on Table 1.

\section{Defuzzification}

Defuzzification on the other hand is to determine the ranking for each of the variables or subvariables. Defuzzification process uses Average of Fuzzy Number (A) to determine the ranking for each of the variables or sub-variables. There are 3 formulas to determine the positions of the agreement:
a) $\quad \mathrm{A}_{\max }=1 / 3 *\left(\mathrm{a}_{1}+\mathrm{a}_{\mathrm{m}}+\mathrm{a}_{2}\right)$
b) $\quad \mathrm{A}_{\max }=1 / 4 *\left(\mathrm{a}_{1}+2 \mathrm{a}_{\mathrm{m}}+\mathrm{a}_{2}\right)$
c) $\quad \mathrm{A}_{\max }=1 / 6 *\left(\mathrm{a}_{1}+4 \mathrm{a}_{\mathrm{m}}+\mathrm{a}_{2}\right)$

This study used formula (a) $A_{\max }=1 / 3^{*}\left(a_{1}+a_{m}+a_{2}\right)$ to calculate the defuzzification values. The value of $\alpha$-cut which is the median value for ' 0 ' and ' 1 ' uses the formula below:

$$
\alpha-\text { cut }=(0+1) / 2=0.5
$$

If the value of $A$ is less than the value of $\alpha$-cut $=0.5$, the item will be omitted which indicates that the consensus of panel of expert rejected the item and vice versa.

\section{Validity and Reliability}

The questionnaires were carefully written and validated before distributed them to the panel of experts. The researcher had put extra caution in the design of the questionnaires to ensure each item produced the desired outcome, while at the same time avoiding bias. The internal and external validity has been reviewed by three panel of experts who have been selected before the questionnaires were being administered to the group of Delphi Panel of Experts.

According to Creswell (2008), reliability is about the accuracy and precision of a measurement procedure and the basis for reliability is consistency. To enhance the reliability of this study, the following processes are developed:

- The purpose of the study, as well as the processes to be used, were discussed with each participant;

- The participants had access to the informed consent and the confidentiality agreement and they had their concerns addressed at all points prior to or during the study; 
Volume 3 Issue 12 (December 2020) PP. 13-28 DOI 10.35631/IJHPL.312002

- The participants were informed that their participation was voluntary and that they could withdraw at any time without penalty;

- The participants were informed that there were no wrong or right answers;

- The participants' identities were concealed and coded to ensure anonymity;

- Each participant had an opportunity to ask questions to ensure they understood the processes;

- Prior to the start of the study, each participant was asked to read and sign the informed consent form;

- Contact information was provided to each participant should further questions or concerns arise during the study.

\section{Research Findings}

Based on the findings, experts' consensus had confirmed the best practices of redeployment policy implementation. The panel of experts agreed with six themes for the best practices as described in Table 2. The items were redeployment guidelines, enforcement, intervention, the selection based on personal background; the selection based on professional background; and teacher readiness.

Based on the FDM analysis, all the six themes obtained more than $75 \%$ consensus of experts which were ranked by defuzzification value as shown in Table 3 . The highest score was 'Selection based on professional background' $(0.7858)$ followed by 'Suggested Interventions' (0.7774); 'Teacher Readiness' (0.7744); 'Implementation of guideline' (0.7659); 'Selection based on personal background' (0.7613); and finally the 'Enforcement' (0.7367).

Table 2: Themes for the Redeployment Best Practices

\begin{tabular}{|c|c|c|}
\hline $\begin{array}{c}\text { 1. Redeployment } \\
\text { Guidelines }\end{array}$ & 2. Enforcement & 3. Interventions \\
\hline $\begin{array}{l}\text { - Briefing about policy } \\
\text { implementation } \\
\text { - Empowerment at all } \\
\text { levels of educational } \\
\text { management } \\
\text { - Frequency of } \\
\text { implementation } \\
\text { - Frequency of database } \\
\text { update } \\
\text { - Teacher selection to be } \\
\text { done at school level } \\
\text { - Priority based on } \\
\text { approved number of } \\
\text { posts }\end{array}$ & $\begin{array}{l}\text { - Set duration for voluntary } \\
\text { redeployment process } \\
\text { - Directive redeployment } \\
\text { order takes place after } \\
\text { voluntary period } \\
\text { - Exception for } \\
\text { redeployment } \\
\text { - Disciplinary action for } \\
\text { non-compliance }\end{array}$ & $\begin{array}{l}\text { - } \begin{array}{l}\text { Selection process in } \\
\text { closed session }\end{array} \\
\text { - } \quad \text { Priority on Teachers' } \\
\text { welfare } \\
\text { - } \text { Incentives } \\
\text { - } \text { Priority for non-optioned } \\
\text { - Advantage to voluntary } \\
\text { redeployment } \\
\text { - } \text { Priority to those who do } \\
\text { not contribute much to } \\
\text { school } \\
\text { - Change of option } \\
\text { - Intervention programme } \\
\text { for Additional Option } \\
\text { - Projection of English } \\
\text { teachers based on needs } \\
\text { - Zero political support } \\
\text { and outside pressure }\end{array}$ \\
\hline
\end{tabular}


- Create new post when necessary

- Offer contract English teachers in states without enough posts.

\begin{tabular}{lll}
\hline $\begin{array}{l}\text { 4. Selection based on } \\
\text { Personal Background }\end{array}$ & $\begin{array}{c}\text { 5. Selection based on } \\
\text { Professional Background }\end{array}$ & 6. Teacher Readiness \\
\hline - Age & - Long service in the same & - Health \\
- Gender & school & - Financial status \\
- Bachelor or single & - Non-administrative post & - Motivation \\
parent status & - Optioned teacher but not & - Work satisfaction \\
- Few children & teaching English. & - Self-Efficacy \\
- Teachers' ethnic & - In time for promotion & - Spouses' mobility \\
background & - CPT with Grade A1 and & - Location of owned \\
- Communication skills & A2 & property \\
- Separated from spouse & & - Commitment to family \\
& & members or parents \\
\hline
\end{tabular}

Table 3: Ranking of Best Practices Themes by Defuzzification Value

\begin{tabular}{lcc}
\hline \multicolumn{1}{c}{ Best Practices Themes } & $\begin{array}{c}\text { Defuzzification } \\
\text { Value }\end{array}$ & Rank \\
\hline Selection based on professional background & 0.7858 & 1 \\
Suggested Interventions & 0.7774 & 2 \\
Teacher readiness & 0.7744 & 3 \\
Implementation of guideline & 0.7659 & 4 \\
Selection based on personal background & 0.7613 & 5 \\
Enforcement & 0.7367 & 6 \\
\hline
\end{tabular}

The items and sub-items of the six best practices themes have been agreed upon by panel of experts and were evaluated using FDM to determine the level of priority recommended by the experts. The analysis of the $42 \mathrm{sub}$ items from the six themes were arranged in Table 4 . The rank of each item showed the level of consensus by panel of experts and score 1 represented the highest level of consensus based on the defuzzification value. The ranking of all the items were justified by their defuzzification values and the combination of all best practices were arranged in rank accordingly as shown in Table 4.

Table 4: Sub-Item Score and Ranking by Defuzzification

\begin{tabular}{|c|c|l|}
\hline Ranking & Defuzzification & \multicolumn{1}{c|}{ Sub-Item } \\
\hline 1 & 0.81 & $\begin{array}{l}\text { Priority based on the needs of option and approved number } \\
\text { of posts in schools }\end{array}$ \\
\hline 2 & 0.80 & $\begin{array}{l}\text { To consider change of option to teachers with low } \\
\text { proficiency (CPT A1 and A2) and have been teaching other } \\
\text { non-option subject more than 3 years. }\end{array}$ \\
\hline
\end{tabular}




\begin{tabular}{|c|c|c|}
\hline Ranking & Defuzzification & Sub-Item \\
\hline 2 & 0.80 & $\begin{array}{l}\text { To implement PITO or option addition programme for non- } \\
\text { optioned teachers who have taught English more than } 3 \\
\text { years. }\end{array}$ \\
\hline 2 & 0.80 & Location of owned property or residence \\
\hline 2 & 0.80 & $\begin{array}{l}\text { Commitment to sick parents or family members or disabled } \\
\text { children }\end{array}$ \\
\hline 2 & 0.80 & Staying far apart from spouse \\
\hline 2 & 0.80 & English optioned but not teaching English subject \\
\hline 2 & 0.80 & Create new post for English teacher when necessary \\
\hline 3 & 0.79 & Selection process to be done in closed session. \\
\hline 3 & 0.79 & $\begin{array}{l}\text { Teacher's level of contribution to students' activities, } \\
\text { school and community. }\end{array}$ \\
\hline 3 & 0.79 & Physically and mentally healthy \\
\hline 3 & 0.79 & Ability to communicate with community in future school \\
\hline 3 & 0.79 & Not holding any administrative posts \\
\hline 3 & 0.79 & $\begin{array}{l}\text { Level of proficiency. i.e. Cambridge Proficiency Test } \\
\text { (CPT) with grade A1 and A2 }\end{array}$ \\
\hline 3 & 0.79 & Explanation to school administrator and teachers \\
\hline 3 & 0.79 & Teachers' welfare to be given priority \\
\hline 4 & 0.78 & Self-efficacy level \\
\hline 4 & 0.78 & Mobility of spouse \\
\hline 4 & 0.78 & Age \\
\hline 4 & 0.78 & Gender \\
\hline 4 & 0.78 & More than 10 years in the same school \\
\hline 4 & 0.78 & $\begin{array}{l}\text { To avoid from the political interference and outside } \\
\text { pressure to redeployment processes, }\end{array}$ \\
\hline 5 & 0.77 & In time for promotion \\
\hline 5 & 0.77 & Teacher selection is done at school level \\
\hline 5 & 0.77 & $\begin{array}{l}\text { Appointment of teacher must be based on the needs not on } \\
\text { the number of graduates }\end{array}$ \\
\hline 5 & 0.77 & $\begin{array}{l}\text { Provide benefit to teachers who apply for voluntary } \\
\text { redeployment i.e. choose the school to go. }\end{array}$ \\
\hline 6 & 0.76 & Motivation level \\
\hline 6 & 0.76 & Financial status \\
\hline 6 & 0.76 & Bachelor or single parent status \\
\hline 6 & 0.76 & Empowerment at all educational management levels \\
\hline 6 & 0.76 & Set a duration for voluntary redeployment process \\
\hline 6 & 0.76 & Offer contract English teachers where necessary \\
\hline 7 & 0.75 & Frequency of implementation \\
\hline 7 & 0.75 & Set criteria for exception to redeployment \\
\hline 8 & 0.74 & Number of children (if married and/or have children) \\
\hline 8 & 0.74 & $\begin{array}{l}\text { Special incentives to teachers who apply for voluntary } \\
\text { redeployment }\end{array}$ \\
\hline
\end{tabular}




\begin{tabular}{|c|c|l|}
\hline Ranking & Defuzzification & \multicolumn{1}{c|}{ Sub-Item } \\
\hline 9 & 0.73 & Career satisfaction level \\
\hline 9 & 0.73 & $\begin{array}{l}\text { Issuance of redeployment order takes place after voluntary } \\
\text { period ends. }\end{array}$ \\
\hline 10 & 0.72 & Frequency of databased update \\
\hline 10 & 0.72 & Minimized non-optioned teachers in schools \\
\hline 11 & 0.71 & Disciplinary action enforces to non-compliance \\
\hline 12 & 0.68 & $\begin{array}{l}\text { Teachers' ethnic background to match the background of } \\
\text { future school / community }\end{array}$ \\
\hline
\end{tabular}

\section{Discussion}

The results consistently indicated that the current redeployment guidelines have many grey areas that might have hindered the effective implementation of the policy. The obvious weakness of the guidelines was that there were no standard criteria of teacher selection for redeployment. This was a major concern as the selection of teachers to be redeployed may have highly contributed to the redeployment order compliance. Teachers would comply to the redeployment order when their professional and personal interests and welfares motivate them (Woolcock, 2018; Dwangu, 2018; Mukeredzi, 2016; Gasa, 2016). In other words, teachers who were to be redeployed need to feel secured and not to be at the losing end (Ololube, 2005; Bishay, 1996). When teachers' welfares were not being considered during the process of redeployment selection, teacher felt frustrated to the system. This is consistent with the studies about teacher motivation done by Watt et al., (2012), Sinclair (2008) and Watt \& Richardson (2007) that teacher psychological fulfilment and well-being are one of the crucial factors related to teacher motivation. Therefore, it is helpful for policy makers to refer to the ranked best practices as the reference to develop a standard criteria of selection that motivates teachers to a win-win situation.

In the efforts to achieve the National Education aspiration on quality student outcomes, policy makers needed to ensure that there were enough English teachers placed in schools. Hamidah (2011) and Shahril@Charil Hj. Marzuki, Hamidah Yusof, Jamal@Yunus Nordin \& Khalip Musa (2014) agreed that quality teachers were one of the major determinants to quality students' outcome. In this case, proper distribution of English language teachers affected students' performance in the subject. According to Kraft (2015), quality teachers had the impact on students' growth along with other factors that support their achievement. Other scholars also agreed that quality teachers have positive impact on students' achievement (Condie, Lefgrenz, \& Sims, 2014; Aaronson, Barrow, \& Sander, 2007; Rivkin, Hanushek, \& Kain, 2005). Furthermore, qualified English language teachers should be able to effectively guide students to develop their true potentials in their language proficiency and in academic for a brighter future (Reyes, M. R., Brackett, M. A., Rivers, S. E., White, M., \& Salovey, P., 2012).

According to the findings of this study, non-compliance to the redeployment order were caused by certain factors. The internal and external factors of policy stakeholders had also contributed to the misdistribution of English teachers. Previous studies do agree that staff redeployment is a solution to the problem of low performance or low production of an organization (Zaitseva, 


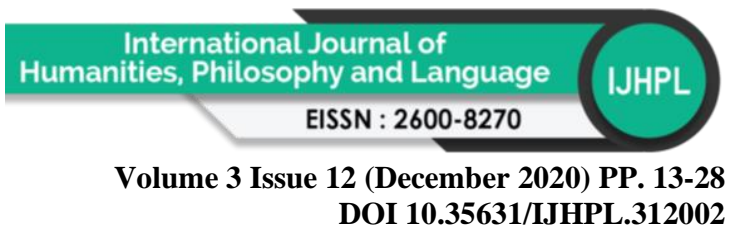

et al., 2020). Hence, the list of redeployment best practices could offer better recommendations on policy implementation based on the consensus of the experts. The ranking of the best practices could help policy implementers in their decision making process especially in terms of selection of teachers for redeployment. According to Kumar, Manonmani \& Kumar (2018), efficient career planning and development of could offer positive feedbacks from the teachers and positive sign implies positive effect on policy implementation. Flaherty, O'Dwyer, Manniz-McNamara, \& Leahy (2017) agreed that positive psychological empowerment will have positive contribution to self-image and behaviour which can contribute to a better and considerate process of redeployment implementation. This is supported by the study by S. Loeb \& J. Myung (2020) that the quality of teaching in a school include the available resources, curriculum, instructional leadership, and by the individuals who teach in each classroom. Selection English teachers to be redeployed among those who are underperform will affect the students' achievement in English Language subject in the new schools after redeployment.

\section{Implications of this study}

Finding of this study found that the policy implementers have done their best to ensure a certain level of success in the redeployment policy implementation. This attitude influenced by their professionalism in carrying out their duties. Overall findings from this study have some implications to the Ministry of Education (MOE) especially to policy makers and School Management Division of MOE as the responsible division to manage redeployment at the national level. Besides that, this study has also impacted the redeployment guidelines.

\section{Implications to $\mathrm{MOE}$}

MOE as the policy maker should accept the reality of teachers' responses towards the implementation of redeployment. MOE needs to remove the barrier faced by policy implementers and English language teachers who are selected to be redeployed. Finding of this study has also alerted the policy makers in MOE to review the redeployment guidelines which should be more comprehensive and practical by policy implementers as well as the stakeholders. The barrier to the success of English Language teacher redeployment was not only in terms of budget allocation but also the empowerment that MOE gives to the lower level educational management. When empowerment given to the other level of education management, MOE needs to monitor the implementation as well. Constant monitoring of the policy implementation could help in achieving the policy targets. Based on the findings, six major areas that need more attention from the policy implementers are the selection criteria for redeployment, intervention mechanism, teacher readiness, redeployment guidelines and also enforcement.

\section{Implication to Implementers}

The mechanism of redeployment policy implementation gives impact to school performance and most of all the students outcome. Policy implementers need to understand that the policy must not be done lightly but the enforcement should be taken seriously to ensure that the rate of compliance will remain high. The list of good practices can help to serve as guidelines for the policy implementers to ensure that the policy is being implemented accordingly. This study is also important for the policy implementers to ensure that the projection of English language teachers is done more carefully by taking into consideration the implementation of redeployment at all levels of education management. Implementers of redeployment should 


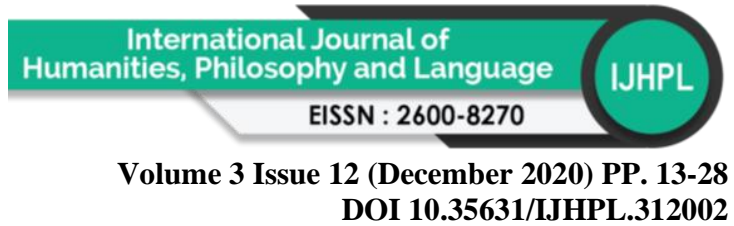

understand that shortage of English language teachers in schools could be the significant factor that affect students' achievement in English Language subject as well as their language acquisition and proficiency. Thus, minimizing the English teacher mismatch could really contribute to achieve the policy target on the standard of English language among students in Malaysia.

The ranking of the good practices is the redeployment policy implementation profile that policy makers may need to refer to as additional guidance in policy decision related to redeployment. The ranked items could help to guide policy makers in the formulation or review of the current redeployment guidelines.

\section{Conclusion}

In short, this study recommended policy makers to ensure that the supply of qualified English language teachers is distributed accordingly to schools. It is also important to increase the quality of teacher training, growing teacher speciality according to subject teaching, reducing gap between gender and racial in a classroom, educational policy could achieve economic goals, and encourage qualified teacher to redeploy at rural area. This is in line with the recent studies on quality teachers that teacher recruitment, teacher retention, and teacher development are areas which can guarantee the improvement of educational opportunities for students (Jessalynn James \& James Wyckoff, 2020).

\section{References}

Alaerts, G. (2020). Adaptive policy implementation: Process and impact of Indonesia's national irrigation reform 1999-2018. World Development, 129, 1-14.

Bahagian Perancangan dan Penyelidikan Dasar Pendidikan (BPPDP) Kementerian Pendidikan Malaysia. (2013a). Laporan Kajian Kebolehlaksanaan Wajib Lulus Bahasa Inggeris Pada Peringkat SPM. Putrajaya:Kementerian Pendidikan Malaysia.

Bahagian Perancangan dan Penyelidikan Dasar Pendidikan, Kementerian Pendidikan Malaysia. (2013b). Pertanyaan dan Jawapan Lisan dan Bertulis serta Ucapan di Parlimen. Putrajaya: Kementerian Pendidikan Malaysia.

Bahagian Perancangan dan Penyelidikan Dasar Pendidikan, Kementerian Pendidikan Malaysia (2012). Pertanyaan dan Jawapan Lisan dan Bertulis serta Ucapan di Parlimen (109th ed.). Putrajaya: Kementerian Pendidikan Malaysia.

BenDavid-Hadar, I. (2015). Entitlement to Education: Fairness Analysis. Second International Handbook on Globalisation, Education and Policy Research, 421-441.

Bhandari, A., \& Mueller, L. (2018). Nation-State or Nation-Family? Nationalism in Marginalized African Societies. Journal of Modern African Studies, 1-36.

Clarke, L., \& McFlynn, P. (2019). All Animals Learn, but Only Humans Teach: The Professional Place of Teacher Educators. Educational Science, 9(192), 1-13.

Condie, S., Lefgrenz, L., \& Sims, D. (2014). Teacher heterogeneity, value added and education policy. Economics of Education Review 40, 76-92

Cowan, J., Goldhaber, D., Hayes, K., \& Theobald, R. (2015). Missing elements in the discussion of teacher shortages. Washington, DC. Retrieved from: http://www.caldercenter.org/sites/default/files/Missing\%20Elements\%20in\%20the\%2 0Di sucssion\%20of\%20Teacher\%20Shortages\%20PDF.pdf 


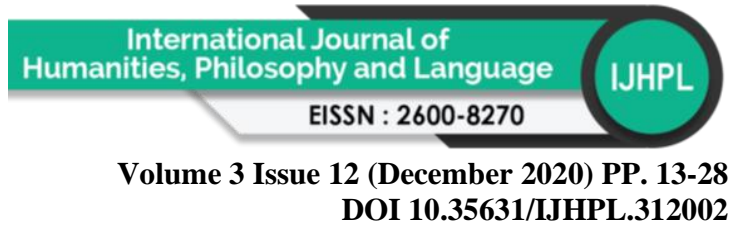

Creswell, J. W. (2008). Educational Research: Planning, conducting, and evaluating quantitative and qualitative research. (3rd Ed). New Jersey: Pearson Prentice Hall.

Dunn, W. N. (1981). Public Policy Analysis: An Introduction. New Jersey: Prentice-Hall, Inc.

Dunn, W. N. (2004). Public Policy Analysis (3rd Editio). New Jersey: Pearson/Prentice Hall.

Dunn, W. N. (2008). Public Policy Analysis-An Introduction (4th ed.). New Jersey: Pearson Education, Inc.

Dwangu, A. M. (2018). The Role of South African Democratic Teachers' Union in The Implementation of Teacher Redeployment Policy in Schools. Magister Educationis in Educational Leadership and Management, 1-151.

Economic Planning Unit (EPU). (2010). Chapter 5 Developing and Retaining A First-World Talent Based. Putrajaya: Jabatan Perdana Menteri.

Educational Planning and Research Division (ERPD). (2017). Data for English language teachers. Putrajaya: Kementerian Pendidikan Malaysia

Flaherty, A., et. al. (2017). The influence of psychological empowerment on the enhancement of chemistry laboratory demonstrators' perceived teaching self-image and behaviours as graduate teaching assistants. Chemistry Education Research and Practice, 1-27. doi: $10.1039 / \mathrm{c} 7 \mathrm{rp} 00051 \mathrm{k}$

Gasa, A. N. (2016). Exploring Instructional Leadership Practices Within the Context of MultiGrade Teaching: Experiences of Principals and Teachers. Dissertation submitted in Partial fulfilment for the Degree of Master of Education in the School of Education in the Discipline, Educational Leadership, Management and Policy, 116.

Ginsburg, M., Ansari, N., Goyee, O. N., Hatch, R., Morris, E., \& Tuowal, D. (2018). Where have all the (qualified) teachers gone? Implications for measuring sustainable development goal target 4.c from a study of teacher supply, demand and deployment in Liberia. African Educational Research Journal, 30-47.

Glewwe, P., Shen, R., Sun, B., \& Wisniewski, S. (2020). Teachers in developing countries. The Economics of Education (371-389). Academic Press.

Gobingca, B. Z., Athiemoolam, L., \& Blignaut, S. E. (2017). Teachers' Perceptions of the Factors Affecting the Implementation of the National Curriculum Statement in the Mthatha Education District. International Journal of Educational Sciences, 18(1-3), 191-199.

Hamidah, Y. (2011). Kecekapan Sistem Pendidikan Malaysia. Malim, Fakulti Pengurusan Dan Ekonomi, UPSI, 21-35.

Hanushek, E. A. (2005). Economic outcomes and school quality. Paris.

Heck, R. H. (2004). Studying Education and Social Policy. New Jersey: Lawrence Erlbaum Associates, Inc.

Higgins, S., Maber, E., Lopes Cardozo, M., \& Shah, R. (2016). The role of education in peacebuilding: country report: Myanmar. Research Consortium Education and Peacebuilding, February, 1-14.

Hoof, L. v., Kraan, M., Visser, N. M., Avoyan, E., Batsleer, J., \& Trapman, B. (2019). Muddying the Waters of the Landing Obligation: How Multi-level Governance Structures Can Obscure Policy Implementation. The European Landing Obligation, 179-196. doi:10.1007/978-3-030-03308-8

House, J. (2018). The Impact of English as a Global Lingua Franca on Intercultural Communication. Intercultural Communication in Asia. Education, Language and Values, 97-114. doi:https://doi.org/10.1007/978-3-319-69995-0 


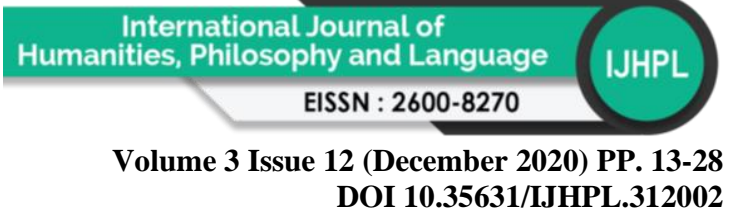

Hsu, C., \& Sandford, B. A. (2007). The Delphi Technique: Making Sense of Consensus. Practical Assessment, Research \& Evaluation, 12(10).

Jessalynn J. and James W. (2020). Teacher labor markets: An overview. The Economics of Education, 355-370. Academic Press.

Kepol, N. (2017). Quality Malaysian English language teachers: Examining a policy strategy. Malaysian Journal of Learning and Instruction, 187-209.

Khan, A. U. (2018). Whither Mother Tongue (in) Education? An Ethnographic Study of Language Policy in Rural Primary Schools in Pakistan. Global Perspectives on Language Education Policies, 23-33.

Köppe, S., \& MacCarthaigh, M. (2019). Public service integration in hard times: Merging unemployment benefit and labour market activation measures. Administration, 67(2), 137-160.

Kota, Z., Hendricks, M., Matambo, E., \& Naidoo, V. (2017). The governance of basic education in the Eastern Cape. Effective States and Inclusive Development Research Centre (ESID), 1-39.

Kumar, V. S., Manonmani, A., \& Kumar, V. R. (2018). Conceptual Model Fit for Career Planning and Development of Employees with Special Reference to Private Sector Banks by Using Structural Equation Model. American Journal of Industrial and Business Management, 8, 1972-1990.

Le, D. M. (2018). Agentic Responses to Communicative Language Teaching in Language Policy: An Example of Vietnamese English Primary Teachers. Global Perspectives on Language Education Policies, 34-45.

Lian, A., \& Sussex, R. (2018). Toward a Critical Epistemology for Learning Languages and Cultures in Twenty-First Century Asia. Intercultural Communication in Asia: Education, Language and Values, 37-54.

Linstone, H. A., \& Turoff, M. (2002). The Delphi Method: Techniques and Applications. Journal of Marketing Research 18(3) DOI: 10.2307/3150755

Mavrogordato, M., \& White, R. S. (2017). Reclassification Variation: How Policy Implementation Guides the Process of Exiting Students From English Learner Status. Educational Evaluation and Policy Analysis, 39(2), 281-310.

Ministry of Education Malaysia. (2010c). To Uphold Bahasa Malaysia \& To Strengthen the English Language. Putrajaya: The Corporate Communication Unit, Ministry of Education Malaysia.

MOE. (2012a). Dasar Pendidikan Kebangsaan. Shah Alam: Giga Wise Network Sdn Bhd.

MOE. (2012b). Malaysia Education Blueprint 2013 - 2025. Putrajaya: Kementerian Pendidikan Malaysia.

Mukeredzi, T. G. (2016). Teacher Professional Development Outside the Lecture Room: Voices of Professionally Unqualified Practicing Teachers in Rural Zimbabwe Secondary Schools. Global Education Review, 84-106.

Ndhlovu, R. M. (1996). The impact of redeployment on the worklife of the educator in the North West Province. University of Johannesburg.

Nemutandani, N. (2004). The management of educator redeployment in Limpopo province. University of South Africa.

Okamoto, K. (2008). Management Process Analysis by the "Ph.P Method." Tokyo: Unpublished. 


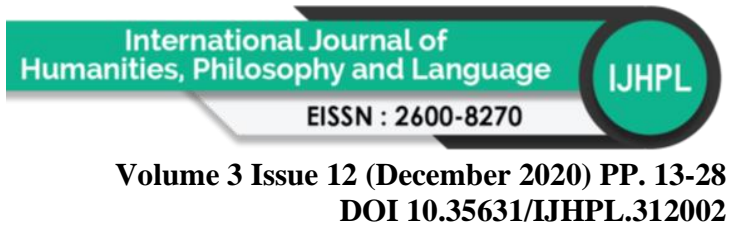

Newman, T. (2018). Policy and Practicality in Timorese Higher Education: Lessons From Lecturers in Development-related Disciplines. Global Perspectives on Language Education Policies, 119-129.

No, F., \& Nguon, S. (2018). Teacher Management and Redeployment: Issues and Practical Ways Forward. Ministry of Education, Youth and Sport: Education Research Council, December, 1-69.

Nurani, F., et. al. (2018). Analysis of Policy Implementation To Decline Mother And Infant Mortality Rate Through The Five C's Protocol (Study Of East Java Province). International Journal of Social and Local Economic Governance (IJLEG), 4(1), 26-31.

Olavarria-Gambi, M. (2017). Policy Implementation: Lessons from the Chilean Policy on Public Management Modernization. The Central European Journal of Public Policy, 11(1), 41-54. doi:10.1515/cejpp-2016-0030

Oshima, K. (2018). Functions of Humor in Intercultural Communication and Educational Environments. Intercultural Communication in Asia: Education, Language and Values, 205-224.

Rai, S., Steenbergen, V., Doyle, A., Kaibo, J., Dukku, A., Kognet, D. A., Lawal, F. (2017). Teacher Supply and Demand in Zamfara. Education Report, Research and Evaluation in Nigeria, Final Report, 1-95.

Rapeta, S. J. (2019). Rightsizing in Public Schools: The Experiences Of Educators And Stakeholders Of Rationalisation And Redeployment As Policy. Doctor of Philosophy in Education in Leadership And Management, 1-348.

Reyes, M., \& Domina, T. (2019). A Mixed-Method Study: Districts' Implementation of Language Classification Policies and the Implications for Male, Hispanic, and LowIncome Middle School Students. Education Policy Analysis Archives, 27(30), 1-31.

Rivkin, S., E. Hanushek, and J. Kain (2005). Teachers, Schools, and Academic Achievement. Econometrica, 73(2), 417-458.

S. Loeb and J. Myung (2020). Economic approaches to teacher recruitment and retention. The Economics of Education. 403-414. Academic Press.

Sabatier, P. A. (2007). Theories of the Policy Process. Colorado: Westview Press.

Shahril @ Charil Hj. Marzuki, Hamidah Yusof, Jamal @ Yunus Nordin dan Khalip Musa. (2014). Perancangan Pendidikan Memacu Transformasi Pendidikan Negara. Tanjong Malim, Perak : Penerbit Universiti Pendidikan Sultan Idris.

Shumba, J., Maphosa, C., Rembe, S., Okeke, C., \& Drake, M. (2016). Teacher Work Related Stress in Early Childhood Education: Some Coping Strategies. Journal Psychology, $150-158$.

Steward, J. (2009). Public Policy Values. London: Palgrave Macmillan.

Sufean, H. (2000). Dasar Pembangunan Pendidikan. Kuala Lumpur: Universiti Malaya.

Snow, D. (2018). Intercultural Communication in English Courses in Asia: What Should We Teach About? Intercultural Communication in Asia: Education, Language and Values, $55-71$.

Spratt, J. (2017). Discourse and Policy. Wellbeing, Equity and Education: A Critical Analysis of Policy Discourses of Wellbeing in Schools, 11-22.

Susani, M. (2017). Challenges Facing the Teaching and Learning Of Accounting in Secondary Schools of The Mthatha Education District. A mini-dissertation submitted in partial 
Volume 3 Issue 12 (December 2020) PP. 13-28 DOI 10.35631/IJHPL.312002

fulfilment of the requirements for the degree of Master Of Education (In Educational Management and Policy), 1-112.

Sussex, R. (2018). Intercultural Communication About Pain. Intercultural Communication in Asia: Education, Language and Values, 181-204. doi:https://doi.org/10.1007/978-3319-69995-0

Thuo, D. N. (2019). Teachers' Professional Development Issues and their Impact on Teachers' Service Delivery. A Case Study of Msimba Secondary School in Mombasa County, Kenya. 2nd Machakos University International Conference (pp. 1-11). Machakos: Machakos University Press.

Turoff, M. (1970). The Design of a Policy Delphi. Technological Forecasting and Social Change, 2(2).

Wang Chih Fong. (2005). Sistem Bantuan Keputusan Penempatan dan Pertukaran Guru. UTM

Weimer, D. L., \& Vining, A. R. (2005). Policy Analysis-Concept and Practice (4th Edition). New Jersey: Pearson/Prentice Hall.

Werbinska, D. (2009). A Profile Of An Effective Teacher Of English : A Qualitative. Hacettepe University Journal of Education, (36), 306-315.

Woolcock, M. (2018). Enhancing public health outcomes in developing countries: from good policies and best practices to better implementation. Scandinavian Journal of Public Health, 46(Suppl 22), 10-18.

Villiers, A. d. (2016). When teachers cannot talk the walk. 32nd World Conference on Music Education (pp. 70-76). Glasgow: International Society for Music Education.

Yani, A., \& Rosita, S. (2016). The Obstacles of Geographical Information System (GIS) Development: A Study of Teachers' Distribution in Sukabumi, Indonesia. Advances in Economics, Business and Management Research, 14, 63-66.

Yokoyama, T. (2018). Official and Realized Hiring Policy of Assistant Language Teachers in Japan. Global Perspectives on Language Education Policies, 106-116.

Zaitseva, I. V., Shlaev, D. V., Poddubnaya, N. V., Linets, G. I., Minkina, T. V., \& Petrenko, V. I. (2020). Research of the labor resource redeployment by mathematical methods of optimal management. IOP Conference Series: Earth and Environmental Science, 421, $1-8$.

Zengele, T. (2019). The Nexus Between Research, Policy and Implementation. Journal of Social Sciences and Humanities, 16(7), 1-11. 